\title{
Uma experiência interrompida: o Colégio Integrado do Centro Pedagógico da Universidade Federal de Minas Gerais (1971)
}

\author{
An interrupted experiment: the Colégio Integrado do Centro Pedagógico da \\ Universidade Federal de Minas Gerais (1971) \\ Un experimento interrumpido: el Colégio Integrado do Centro Pedagógico da \\ Universidade Federal de Minas Gerais (1971)
}

\author{
Alessandra Soares Santos \\ Universidade Federal de Minas Gerais (Brasil) \\ https://orcid.org/0000-0002-8396-9452 \\ http://lattes.cnpq.br/4898543565872200 \\ alessandrast@ufmg.br
}

\section{Resumo}

O artigo aborda a experiência do Colégio Integrado do Centro Pedagógico da UFMG, realizada em 1971, a partir de uma perspectiva que buscou compreender tanto a dinâmica interna desta instituição escolar, quanto sua relação com a política educacional estabelecida pela ditadura civil-militar. O Colégio Integrado propôs uma estrutura e um currículo próprio que pretendeu representar uma das possibilidades mais arrojadas de ensino e, ao mesmo tempo, se adequar às novas demandas da reforma do ensino de $1^{\circ}$ e $2^{\circ}$ graus que estava em discussão em nível federal e que viria a ser oficializada no ano seguinte. Entretanto, esta experiência foi interrompida pela proposta de profissionalização obrigatória prevista na lei e também pelas circunstâncias internas à universidade. Concluímos que esta experiência se juntou a outras do mesmo período que, pretendendo inovar o ensino secundário, não foi capaz de superar os entraves de um sistema educacional conservador e pragmático.

Palavras-chave: História da Educação. História das Instituições Educacionais. Reforma do Ensino de $1^{\circ}$ e $2^{\circ}$ graus. 


\begin{abstract}
The article discusses the experience of the Colégio Integrado do Centro Pedagógico da UFMG, held in 1971, soughtting to understand the school dynamics, as well as its relationship with the educational policy established by the Brazilian civil-military dictatorship. The Colégio Integrado was planned with its own structure and curriculum, that intended to represent one of the most daring possibilities of teaching and to adjust with new demands of the Brazilian 1st and 2nd degrees education reform at the federal level, which became official by the following year. However, this experience was interrupted by a mandatory professionalization proposal, created by a new law, as well as by university internal circumstances. We conclude that this experience was joined by the others in the same period that had intend to innovate high school education. But them were not able to overcome some obstacles of a conservative and pragmatic educational system.
\end{abstract}

Keywords: History of Education. Institutional History of Schools. Education Reforms History $2^{\text {nd }}$ degrees.

\title{
Resumen
}

El artículo analiza la experiencia del Colegio Integrado do Centro Pedagógico da UFMG, realizada en 1971, desde una perspectiva que comprende tanto la dinámica interna de esta institución escolar, como su relación con la política educativa instaurada por la dictadura cívicomilitar en Brasil. El Colegio Integrado propuso una estructura y un plan de estudios propio que pretendía representar una de las posibilidades más atrevidas de la docencia y, al mismo tiempo, adaptarse a las nuevas demandas de la reforma de la educación de $1^{\circ}$ y $2^{\circ}$ grados que se estaba discutiendo a nivel federal. Sin embargo, esta experiencia se vio interrumpida por la propuesta de profesionalización obligatoria prevista en la ley y también por las circunstancias internas de la universidad. Concluimos que esta experiencia se sumó a otras del mismo período que, con la intención de innovar la educación secundaria, no logró superar los obstáculos de un sistema educativo conservador y pragmático.

Palabras clave: Historia de la educación. Historia de las Instituciones Educativas. Reforma educativa de $1^{\circ}$ y $2^{\circ}$ grados. 


\section{Introdução}

"Um sonho que não se realizou". Com esta frase a professora emérita da Faculdade de Educação da Universidade Federal de Minas Gerais, Magda Soares, que integrou o Grupo de Trabalho responsável pelo projeto original da reforma do ensino durante a ditadura civil-militar, sintetizou a intenção dos especialistas responsáveis pela elaboração do anteprojeto da lei $\mathrm{n}^{\circ}$ 5.692/71. Segundo ela, a reforma do ensino médio pretendida por estes especialistas visava garantir que "uma base de estudos gerais prepararia os jovens que o desejassem para o ensino superior, ao mesmo tempo em que uma habilitação de nível médio já lhes possibilitaria a ocupação, o que beneficiaria sobretudo os mais pobres" (apud BELTRÃO, 2017). Dentre os pressupostos da reforma idealizada, destaca-se a defesa de uma proposta única de ensino médio para todo o país que fosse capaz de integrar o desenvolvimento intelectual do adolescente com sua formação profissional ou universitária. Ao contrário da lei aprovada, que tornou obrigatória a profissionalização do ensino de $2^{\circ}$ grau, o anteprojeto previa espaço para a formação geral e acadêmica dos estudantes como alternativa à formação profissional. Neste artigo, apresentamos a experiência do Colégio Integrado do Centro Pedagógico da UFMG, realizada em 1971, que se aproximou daquele "sonho não realizado". Entretanto, o empreendimento foi interrompido com a aprovação da lei federal n ${ }^{0} 5.692 / 71$.

Quais foram as concepções de ensino e educação que fundamentaram a realização desta experiência? Como se deu a organização pedagógica e curricular deste curso? Houve aproximações entre essas concepções e aquelas que nortearam os trabalhos do grupo de especialistas responsáveis pela Reforma de 1971? Qual foi o envolvimento dos educadores que atuaram em funções executivas e de assessoramento desta política? Em quê essa experiência inovadora contrariou a política educacional instituída pela lei de 1971 resultando na sua interrupção?

Em termos teórico-metodológicos, esta pesquisa se insere em um campo específico da história da educação que é o da história das instituições educacionais. Por um lado, buscamos compreender a dinâmica interna de uma instituição escolar cuja identidade se configura dentro do contexto universitário; por outro, procuramos compreendê-la em sua multidimensionalidade, superando uma história meramente descritiva, mas oferecendo uma interpretação que a localize no movimento histórico de um desenvolvimento geral do país (GATTI JÚNIOR, 2002; BUFFA, 2002; MAGALHÃES, 2004). Assim, para responder àquelas questões, lançamos mão de documentos e legislações pertinentes vigentes à época, além de fontes que fizeram parte da cultura escolar do Colégio Integrado do Centro Pedagógico, como atas de reuniões, manuais sobre a organização escolar voltados para os estudantes e suas famílias, ofícios expedidos, bem como de fontes da imprensa, entrevistas e relatos autobiográficos. Estes últimos contribuíram para a compreensão da trajetória profissional dos agentes responsáveis tanto pelo planejamento e a organização do Colégio Integrado do Centro Pedagógico da UFMG, quanto pela elaboração do anteprojeto da lei que resultou na Reforma do Ensino de $1^{\circ}$ e $2^{\circ}$ graus naquele momento.

O título desta pesquisa dialoga com dois livros de temática semelhante. O primeiro, "Uma experiência interrompida", de Henriette Amado et ali, publicado em 1972, sobre o Colégio Estadual André Maurois (CEAM), no Rio de Janeiro. O segundo, "Uma experiência de educação interrompida", de Terezinha Rosa Cruz, publicado em 2001, sobre o Centro Integrado de Ensino Médio da Universidade de Brasília (CIEM-UnB). Ambas as experiências pretenderam desenvolver propostas educacionais inovadoras nos anos 1960, no contexto da ditadura civil-militar, e foram subitamente interrompidas em 1971. A história do Colégio Integrado do Centro Pedagógico da UFMG que abordamos aqui se junta àquelas experiências em suas semelhanças e diferenças. 


\section{A educação básica no contexto universitário}

A história do que viria a se transformar em Centro Pedagógico da UFMG começou em 1954, quando foi inaugurado o Ginásio de Aplicação. Sua criação atendia a um decreto assinado pelo então presidente Eurico Gaspar Dutra que estabelecia a obrigatoriedade da criação de um ginásio de aplicação nas faculdades de filosofia federais destinados à prática docente dos alunos matriculados no curso de didática daquelas faculdades. ${ }^{1}$ Naquele momento, entretanto, a Faculdade de Filosofia de Minas Gerais ainda era uma instituição particular, vinculada aos professores do tradicional Colégio Marconi, em Belo Horizonte, e não estava sujeita àquele decreto. Somente em 1948 ela foi incorporada à Universidade de Minas Gerais (UMG), passando a funcionar no prédio do tradicional Instituto de Educação durante sua estadualização, tendo sido federalizada no ano seguinte, em 1949.

Portanto, seguindo as determinações daquele decreto, as faculdades de filosofia criadas ou incorporadas às universidades federais após sua expedição, deveriam se encarregar de colocar em funcionamento os ginásios de aplicação a partir do momento em que tivessem alunos matriculados no curso de Didática. Em Minas Gerais, estas condições foram alcançadas em 1954, quando foi inaugurado o Ginásio de Aplicação da UFMG nas instalações do antigo Colégio Afonso Arinos, situado ao lado da Faculdade de Filosofia, em Belo Horizonte. Após quatro anos, em 1958, quando os 47 alunos da primeira turma do ginásio terminaram a $4^{\mathrm{a}}$ série, equivalente ao ensino fundamental, o Ginásio de Aplicação se transformou em Colégio de Aplicação e passou a ofertar os cursos Clássico e Científico, equivalente ao ensino médio.

Em 1968, na esteira da reforma universitária e do plano de reestruturação da UFMG, o Colégio de Aplicação da Faculdade de Filosofia se transformou em Centro Pedagógico. Originalmente, segundo o depoimento do reitor à época, Gerson de Brito Mello Boson, o Centro Pedagógico foi "idealizado para ser um centro de formação e preparação de professores de todos os graus, inclusive de ensino superior" (BOSON, 1998, p. 91). A proposta foi apresentada à Universidade de Houston na ocasião de uma viagem do reitor aos Estados Unidos, convidado pelo governo daquele país. A ideia era que fosse formada uma associação de universidades do continente americano, coordenada pela universidade estadunidense, que seria encarregada de manter um Centro Interamericano de Pós-Graduação na UFMG. Cada universidade associada teria um número determinado de vagas para a formação de seus professores neste centro. Segundo o ex-reitor, "os professores seriam recrutados no mundo inteiro, porque haveria, sem dúvida, recursos suficientes, e a projeção da Universidade Federal de Minas Gerais seria extraordinária" (BOSON, 1998, p. 91). Entretanto, sua viagem aos Estados Unidos para as tratativas deste acordo foi interrompida pela notícia de que seu mandato na reitoria da UFMG teria sido cassado pela Junta Militar que exercia a Presidência da República em outubro de 1969.

Pelo estatuto da UFMG de 1971, o Centro Pedagógico assumiu oficialmente a atribuição de reunir todas as atividades de educação de nível pré-primário, primário e médio na universidade. Assim, este centro estaria vinculado administrativamente à reitoria e se integraria à Faculdade de Educação, recém-criada, para fins de pesquisa e treinamento de professores em todos os níveis. De fato, as mudanças empreendidas e o esforço para implementá-las estavam respaldadas pela ideia de progresso associada ao projeto modernizante da própria universidade. Por um lado, o mote dessa perspectiva modernizadora da instituição, segundo Oliveira e Faria Filho (2019), estava justamente na valorização da pesquisa e no estabelecimento de uma política de integração entre a universidade e a comunidade. Por outro, a implementação deste projeto modernizador também passava pela integração das faculdades dispersas em um campus universitário. A reestruturação da educação básica dentro da universidade na órbita do Centro Pedagógico,

\footnotetext{
${ }^{1}$ Decreto-lei no 9.053, de 12 de março de 1946. Cria um ginásio de aplicação nas Faculdades de Filosofia do País. Legislação Informatizada da Câmara dos Deputados.
} 
portanto, foi parte deste projeto modernizador. As obras para a construção de seu prédio no campus tiveram início já em 1969.

Mas a proposta de criação de um centro para reunir todas as atividades da educação básica na universidade não foi realizada sem entraves. Desde 1966, paralelamente às atividades do Colégio de Aplicação, funcionava na UFMG o Colégio Universitário (Coluni). Os colégios universitários foram criados quando a Lei de Diretrizes e Bases da Educação Nacional (LDB) de 1961 tornou facultativa às universidades a instituição de colégios destinados a ministrar o ensino do $3^{\circ}$ ano do chamado ciclo colegial para preparar os estudantes do ensino secundário para o vestibular. Na UFMG, o Colégio Universitário foi implantado em 1965 com o entusiasmo do então reitor Aluísio Pimenta pela proposta. Logo uma comissão foi composta com a professora Magda Soares ${ }^{2}$, da Faculdade de Educação, e com o professor Hélcio Werneck ${ }^{3}$, da Faculdade de Medicina, para desenvolver a concepção pedagógica e didática do novo colégio. Um prédio sob medida foi construído no campus para atender a essa proposta, para onde em 1972 foram transferidas as faculdades de Educação e de Biblioteconomia, dando fim àquele empreendimento.

Ainda em 1966, os alunos do Colégio de Aplicação fizeram um abaixo-assinado solicitando a isenção da prestação do exame de admissão ao Colégio Universitário, visto que faziam parte da mesma modalidade de ensino, na mesma instituição. Entretanto, a reivindicação não foi atendida pela direção do colégio sob os argumentos de que o teste de admissão possibilitaria uma "visão panorâmica da amostra necessária à adaptação dos programas e métodos de ensino, visando o bom sucesso dos vários cursos" e que os testes para ingresso no Colégio de Aplicação não procurariam avaliar os mesmos aspectos. ${ }^{4}$ Além disso, o ofício dirigido ao reitor mencionava ainda o risco da abertura de uma exceção diante de outras instituições de ensino que supostamente poderiam fazer a mesma solicitação. A recusa tornava explícita a distinção entre as iniciativas que visavam o atendimento aos estudantes da educação básica no interior da universidade, chegando mesmo a equiparar as demandas do Colégio de Aplicação a de outros colégios sem vínculo com a UFMG.

Essas diferenças se tornaram ainda mais evidentes a partir dos estudos para a reforma de 1968 e a reorganização dos cursos universitários, incluindo aqueles da educação básica. Em 1969, quando uma decisão da reitoria manteve o funcionamento do Colégio Universitário com a mesma estrutura do ano anterior devido à indefinição quanto ao formato de sua incorporação ao Centro Pedagógico, o então diretor do centro, professor Hélio Pontes, solicitou ao colegiado do Coluni que os estudantes do Colégio de Aplicação fossem admitidos sem concurso. $\mathrm{O}$ colegiado, entretanto, rejeitou o pedido por unanimidade. ${ }^{5}$ É preciso ressaltar que havia, entre a equipe de professores do Colégio Universitário, o interesse de manter a seleção dos melhores estudantes da cidade, o que significava atrair os melhores alunos das escolas mais tradicionais de Belo Horizonte (COELHO, 1998).

Entre 1968 e 1970, o assunto "Centro Pedagógico" foi pauta recorrente das reuniões do Colegiado do Colégio Universitário. Da revisão do regimento interno ao número de salas e professores, passando pela promoção dos professores ao cargo de assistentes, tudo no Colégio

\footnotetext{
2 A professora Magda Soares se formou em Letras Neolatinas pela UFMG em 1953. Lecionou na Faculdade de Educação e recebeu o título de professora emérita da instituição em 1998, tendo desenvolvido suas pesquisas no campo da alfabetização.

${ }^{3}$ O professor Hélcio José Lins Werneck se graduou em Medicina pela UFMG em 1954, obteve o doutorado em Anatomia Humana em 1957 e se tornou livre-docente em 1958. Foi professor do curso Preparatório para o curso de Medicina (Pré-Médico) entre 1954 e 1963 e diretor deste curso entre 1965 e 1967.

${ }^{4}$ Ofício $n^{\circ} 133$ de Hélcio Werneck, diretor geral do Colégio Universitário, para Aloísio Pimenta, reitor da Universidade Federal de Minas Gerais. Belo Horizonte, 7 de novembro de 1966. Centro de Documentação e Memória da Faculdade de Educação da UFMG.

${ }^{5}$ Ata da Reunião do Colegiado do Colégio Universitário da UFMG. Belo Horizonte, 19 de dezembro de 1969. Arquivo do Centro Pedagógico da UFMG.
} 
Universitário dependia do plano de estruturação do Centro Pedagógico. Por isso, em setembro de 1968, o colegiado registrou em ata a "impossibilidade do Coluni permanecer omisso diante da implantação do Centro Pedagógico", resolvendo convocar um membro da Comissão de Planejamento do Centro Pedagógico para ir ao colégio expor o plano de estruturação do mesmo. ${ }^{6}$ Somente em agosto de 1969, entretanto, o diretor geral do Coluni, professor Edmar Chartone de Souza, comunicou ao Colegiado que, desde julho daquele mesmo ano, o Coluni já deveria se chamar Colégio Integrado do Centro Pedagógico. ${ }^{7}$ Diante da expectativa de, a partir de 1970, o Colégio Integrado contar com uma turma de $1^{\circ}$ ano, além da turma de $3^{\circ}$ ano, e da necessidade de se estabelecer novos currículos e programas para cada matéria, a professora Magda Soares se prontificou a orientar os professores. ${ }^{8}$

Antes de sair do papel, a ideia do Colégio Integrado já gerava grande expectativa e chegou a ser tema de uma longa reportagem do jornal carioca Correio da Manhã, ainda em 1969, na qual era descrito o funcionamento do extinto Colégio Universitário. Sob o título de "Nova experiência pioneira: o Colégio Integrado em Minas", a matéria destacava que este modelo de colégio representava "uma conquista, no sentido de lançar pontes entre o curso médio e o superior". ${ }^{9} \mathrm{Na}$ legenda da foto que ilustra a matéria, há a menção ao fato de que o projeto do curso teria sido apresentado à Organização dos Estados Americanos (OEA), assunto que não é retomado no texto e sobre o qual não encontramos melhores informações. ${ }^{10}$

Buscando conciliar os interesses daqueles que defendiam a manutenção da autonomia do Colégio Universitário, inicialmente sua substituição pelo Colégio Integrado incorporado ao Centro Pedagógico não previa alteração na estrutura básica de seu funcionamento, que continuaria com os mesmos departamentos e setores. O prestígio dos docentes que atuavam no Colégio Universitário pesou para essa manutenção, bem como os bons resultados que ele alcançava. De fato, poucas mudanças foram previstas, dentre as quais constavam a substituição da diretoria de ensino por uma assessoria de ensino e a transformação da diretoria geral em coordenadoria de curso. ${ }^{11}$ Depois, cogitou-se que o Colégio Integrado se encarregaria do curso de adaptação do Instituto de Ciências Exatas (ICEX) e do Instituto de Ciências Biológicas (ICB) e que a assessoria de ensino seria extinta, ${ }^{12}$ o que não se realizou.

Finalmente, em setembro de 1970, o anteprojeto de resolução do Centro Pedagógico da UFMG foi aprovado pela Coordenação de Ensino e Pesquisa da UFMG e, em 1971, já constava no Regimento da Universidade. Por este documento, estabeleceu-se oficialmente que o Colégio Universitário passaria, a partir de 1971, a Colégio Integrado do Centro Pedagógico e a vinculação administrativa e pedagógica do Centro foi formalmente atribuída à Faculdade de Educação. ${ }^{13}$ Para a professora Maria Lisboa de Oliveira, "foi uma situação camuflada e só depois descobrimos que o Colégio Universitário havia acabado" (apud PAUL, 1988, p. 7).

\footnotetext{
${ }^{6}$ Ata da Reunião do Colegiado do Colégio Universitário da UFMG. Belo Horizonte, 24 de setembro de 1968. Arquivo do Centro Pedagógico da UFMG.

${ }^{7}$ Ata da Reunião do Colegiado do Colégio Universitário da UFMG. Belo Horizonte, 22 de agosto de 1968. Arquivo do Centro Pedagógico da UFMG.

${ }^{8}$ Ata da Reunião do Colegiado do Colégio Universitário da UFMG. Belo Horizonte, 5 de setembro de 1969. Arquivo do Centro Pedagógico da UFMG.

${ }^{9}$ DORNELLES, L. Nova experiência pioneira: Colégio Integrado em Minas. Correio da Manhã, edição $\mathrm{n}^{\circ}$ 23.487, Rio de Janeiro, 8 de novembro de 1969. p. 13.

${ }^{10}$ Em seu discurso ao passar o cargo de reitor da UFMG para o professor Gerson de Brito Mello Boson, ainda em 1967, Aluísio Pimenta faz referência ao fato de que o Colégio Universitário teria recebido aprovação da UNESCO (PIMENTA, 1984), mas não tivemos como confirmar se tratava da mesma deferência feita pela OEA.

${ }^{11}$ Ata da Reunião do Colegiado do Colégio Universitário da UFMG. Belo Horizonte, 14 de outubro de 1970. Arquivo do Centro Pedagógico da UFMG.

${ }^{12}$ Ata da Reunião do Colegiado do Colégio Universitário da UFMG. Belo Horizonte, 23 de setembro de 1970. Arquivo do Centro Pedagógico da UFMG.

${ }^{13}$ Ata da Reunião do Colegiado do Colégio Universitário da UFMG. Belo Horizonte, 23 de setembro de 1970. Arquivo do Centro Pedagógico da UFMG.
} 
Por meio da Comissão Especial de Planejamento do Colégio Integrado do Centro Pedagógico da UFMG, coordenada pelo então diretor geral do Colégio Universitário, professor Edmar Chartone de Souza, ${ }^{14}$ e pela diretora de ensino do Centro Pedagógico, professora Magda Soares, pretendeu-se desenvolver uma experiência inteiramente nova em educação. Antes de integrar o quadro docente da UFMG, o professor Chartone lecionou no Centro Integrado de Ensino Médio da Universidade de Brasília (CIEM-UnB), tendo inclusive proferido a aula inaugural daquele centro em 1964 (CRUZ, 2001). Nele permaneceu apenas até o ano seguinte, durante a chamada "crise de 1965 " na UnB, quando o campus foi ocupado pelas forças policiais e 15 professores foram presos arbitrariamente, incluindo o professor Hélio Pontes ${ }^{15}$, que viria a se tornar diretor do Centro Pedagógico em 1969. Em protesto contra os graves acontecimentos, Chartone e outros 222 professores da universidade se demitiram voluntariamente, deixando a UnB com apenas 82 professores e uma crise sem precedentes (RELATÓRIO, 2016). Embora tenha permanecido pouco mais de um ano, de lá trouxe uma experiência inovadora de educação.

A professora Magda Soares também passou pelo CIEM quando, em janeiro de 1968, foi designada pelo reitor da UnB, o mineiro Caio Benjamin Dias ${ }^{16}$, como representante da reitoria para "proceder a um exame da situação do Centro Integrado de Ensino Médio - CIEM, podendo, para tanto, convocar os servidores da Universidade que julgar necessários para auxiliá-la nesse trabalho", para o qual se previu o recebimento de "pro labore" equivalente ao nível salarial de um professor titular. ${ }^{17}$ Infelizmente, não encontramos nenhum relatório relativo aos objetivos e resultados deste exame. Entretanto, sabemos que, no final de 1967, o CIEMUnB viveu uma grave crise interna desencadeada pela saída de seu diretor, José Aloísio Aragão, que tinha sido fundador e principal responsável pelas ações propostas pelo colégio, e pelos protestos estudantis contra a expulsão de uma aluna, o que resultou na expulsão de mais 23 estudantes. A designação da professora Magda Soares para analisar a situação do CIEM-UnB em janeiro de 1968 teve relação direta com os problemas enfrentados pelo então reitor após esta crise. Na entrevista que concedeu para esta pesquisa, ela relata que

o que se sabia era que o CIEM era um conjunto de jovens absolutamente insubordinados e questionadores. E um professor nosso, da medicina, Dr. Caio Benjamin Dias, foi convidado para ir para Brasília para ser reitor da Universidade de Brasília. Um dos problemas que ele tinha era o tal do CIEM que era um núcleo de resistência ao militarismo, de alunos muito insubordinados etc. E aí ele me chamou. Infelizmente eu não pude recusar porque ele era um amigo muito querido, muito próximo, um médico que foi meu médico desde a infância. Então ele me chamou a mim e mais dois ou três da educação, fez uma comissão para a gente ir lá ver que solução dava para o CIEM. E foi difícil porque era um colégio quase impenetrável.

14 O professor Edmar Chartone se formou em Ciências Naturais pela UFMG em 1963. Tornou-se professor titular da instituição em 1991 e recebeu o título de professor emérito em 2006, tendo desenvolvido suas pesquisas no campo da genética.

${ }^{15} \mathrm{O}$ professor Hélio Pontes esteve vinculado à Faculdade de Ciências Econômicas da UFMG até 1963, quando se mudou para Brasília a convite de Darcy Ribeiro para se integrar ao corpo docente da recém-criada Universidade de Brasília. Retornou à Belo Horizonte em 1965 e reassumiu o cargo de docente na UFMG, desta vez na Faculdade de Educação, onde se tornou professor emérito anos mais tarde. Em meados dos anos 1970, retornou à Brasília para assumir o cargo de Secretário de Apoio Administrativo do MEC.

${ }^{16}$ Médico diplomado pela UFMG, Caio Benjamin Dias foi fundador da Faculdade de Ciências Médicas de Belo Horizonte. Foi escolhido pelos militares reitor da UnB em 1967, cargo que exerceu até 1971, quando foi designado secretário de Educação de Minas Gerais pelo governador Rondon Pacheco. Entre 1978 e 1989, foi membro do Conselho Estadual de Educação.

${ }^{17}$ Ato da Reitoria da Universidade de Brasília n o 016/68. Brasília, 15 de janeiro de 1968. AtoM-UnB. 
A gente foi para dizer o que era aquilo, para fazer uma análise do CIEM. E a gente fez um relato para reitoria e a solução foi vamos fechar isso, acabar com isso porque não tem solução e não tem sentido a universidade ficar mantendo esse centro de ensino médio. ${ }^{18}$

O CIEM-UnB foi uma escola de ensino médio em tempo integral, cujo projeto pedagógico foi idealizado por Darcy Ribeiro. Sua criação foi ao encontro de uma concepção que atribuía à universidade o papel de dar atenção completa à educação, ou seja, "fazer com que a problemática do ensino primário e médio fosse problemática da universidade, tal como os são tantos outros campos da prática da ciência", conforme declarou Darcy Ribeiro (apud CRUZ, 2001, p. 51). Criado antes mesmo da Faculdade de Educação da UnB, suas finalidades eram criar e divulgar um novo modelo educacional para o ensino médio e as experiências pedagógicas realizadas, além de funcionar como centro de experimentação e demonstração. Seu currículo compreendia três semestres letivos com as disciplinas básicas recomendadas pelo Conselho Federal de Educação e outros três semestres com disciplinas optativas. O CIEM se destacou por promover uma educação pautada pela "liberdade com responsabilidade", na qual os estudantes eram estimulados a se desenvolverem intelectualmente com liberdade de pensar, falar e se posicionar (CRUZ, 2001). A instituição funcionou entre 1964 e 1970, tendo sido fechada durante as férias de janeiro de 1971 por motivos de ordem política.

O Colégio Integrado do Centro Pedagógico da UFMG teve em comum com o CIEM-UnB o trabalho de unidade pedagógico-administrativa, a relação com a Faculdade de Educação, visando ser um centro de experimentação escolar, o tempo integral de ensino em regime semestral, o foco na interdisciplinaridade, o sistema de crédito com matrícula por disciplina, o currículo diversificado com oferta de disciplinas obrigatórias e optativas. Analisando a organização do CIEM-UnB, Cruz (2001, p. 72) ressaltou que "era uma cópia do sistema da UnB, mas totalmente dentro da LDB", o que poderia ser também observado no Colégio Integrado do Centro Pedagógico, cujo currículo teria sido proposto "fugindo da Lei de Diretrizes e Bases"19 apenas no que se refere à atribuição que a lei de 1961 dava aos estados de organizar os ensinos primário e secundário. Em 1971, além do Colégio Integrado, o Centro Pedagógico mantinha o Curso Ginasial do ex-Colégio de Aplicação, o Curso Normal, que tinha a pretensão de se tornar uma das habilitações profissionais do Colégio Integrado, o Curso de Adaptação que era oferecido aos alunos excedentes aprovados nos exames vestibulares e o Colégio Técnico.

O Colégio Integrado estabeleceu uma estrutura e um currículo próprio que pretendia representar uma das possibilidades mais arrojadas de ensino e, ao mesmo tempo, se adequar às novas demandas da reforma da educação que estava em discussão em nível federal e que viria a ser oficializada no ano seguinte. Essa proposta ganhou forma concomitantemente às discussões do segundo GT instituído pelo governo civil-militar para elaborar o anteprojeto da reforma de $1^{\circ}$ e $2^{\circ}$ graus que também contou com a participação da professora Magda Soares. ${ }^{20}$ O Colégio Integrado oferecido pelo Centro Pedagógico durante o ano de 1971 passou a figurar como um laboratório para o que poderia ser adotado nas escolas de $2^{\circ}$ grau brasileiras. De fato, em reunião realizada em novembro de 1970, a professora Magda Soares acentuou os objetivos do Colégio Integrado aos professores do antigo Coluni. Segundo ela, a experiência deveria

\footnotetext{
${ }^{18}$ Magda Soares. Belo Horizonte, 31 out. 2020 (Entrevista realizada por via remota para esta pesquisa).

${ }^{19}$ Ata da Reunião do Colegiado do Colégio Universitário da UFMG. Belo Horizonte, 4 de novembro de 1970. Arquivo do Centro Pedagógico da UFMG.

${ }^{20}$ Decreto $n^{\circ} 66.600$ de 20 de maio de 1970. Cria Grupo de Trabalho no Ministério da Educação e Cultura para estudar, planejar e propor medidas para a atualização e expansão do Ensino Fundamental e do Colegial. Legislação Informatizada da Câmara dos Deputados.
} 
constar como uma pesquisa na área da educação e, por isso, salientou também a importância da sistematização dos trabalhos e a necessidade de divulgação periódica dos resultados obtidos. ${ }^{21}$

Entretanto, esta experiência foi interrompida pela proposta de profissionalização obrigatória prevista na lei da reforma do ensino de 1971 e também pelas circunstâncias internas à universidade no momento de reorganização de sua estrutura física e administrativa. Por determinação da lei $\mathrm{n}^{\circ} 5.692$, todas as escolas de $2^{\circ}$ grau deveriam oferecer apenas cursos profissionalizantes para formar a mão de obra técnica necessária às atividades econômicas do país. Para Cunha (2014, p. 914), "essa lei representou uma ruptura contra as tendências que se firmavam tanto na política educacional quanto nas concepções predominantes entre os educadores e os administradores educacionais", pois nenhuma corrente educacional expressiva dentro ou fora do Ministério da Educação e Cultura (MEC) defendia a concepção da profissionalização obrigatória no ensino de $2^{\circ}$ grau. Segundo o mesmo autor, "para que a concepção da profissionalização universal e compulsória prevalecesse, foi preciso que o MEC recorresse a procedimentos autoritários" (CUNHA, 2014, p. 918). Por outro lado, não podemos negar que as principais mudanças educacionais da ditadura civil-militar encontraram legitimidade numa burocracia estatal formada por educadores que compartilhavam um "pragmatismo tecnocrático" (GARCIA, 1980), conforme veremos.

\section{A reforma do ensino de $1^{\circ}$ e $2^{\circ}$ graus: concepções educacionais em disputa}

Segundo Cury et ali (1982), as ideias que foram debatidas a partir de meados da década de 1960 e que levaram à proposta da lei da reforma de ensino de 1971 revelavam uma mudança de perspectiva quanto as relações entre escola e trabalho no Brasil, embora não estivessem muito definidos os contornos dessas relações. Assim, de acordo com os mesmos autores, "elas foram operacionalizadas como relação entre escola e mercado de trabalho ou como relação entre escola e emprego" (CURY et ali, 1982, p. 27). Essas ideias ganharam forma em um contexto de acelerado crescimento da economia brasileira impulsionada pela indústria e pela urbanização. $\mathrm{O}$ chamado "milagre econômico" impôs o desafio de inserir o país numa nova organização do mercado de trabalho. A carência de técnicos de nível médio em algumas áreas atrelada à suposta valorização da escolaridade formal por parte das empresas foi responsável pelas relações estreitas que se desenvolveram entre a escola e o mercado. Ao sistema educacional recaiu a maior responsabilidade pelo preparo dos recursos humanos que, acreditava-se, seriam necessários à modernização do setor econômico do país (CURY et ali, 1982).

Naquele momento a presença americana foi marcante para conformar a compreensão dessas relações entre educação e trabalho no país. Segundo Romanelli (1986), além de assistência financeira e assessoria técnica junto às autoridades e instituições educacionais, a atuação da Agência para o Desenvolvimento Internacional (AID) no Brasil incluía "um tipo de ação que implicava doutrinação e treinamento de órgãos e pessoas intermediárias brasileiras, com vistas obviamente a uma intervenção na formulação de estratégias que a própria AID pretendia fosse adotada pelos dirigentes, órgãos e instituições educacionais" (ROMANELLI, 1986, p. 210). Em 31 de março de 1965, exatamente um ano após a tomada do poder pelos militares, foi assinado o primeiro acordo sobre o ensino médio entre o governo brasileiro e a Agência Norte-Americana para o Desenvolvimento Internacional (USAID). O acordo partia da compreensão de que a responsabilidade pelos ensinos primário e secundário dada aos estados pela Lei de Diretrizes e Bases da Educação Nacional de 1961 resultava em dificuldades de ordem prática devido a uma suposta carência de experiência quanto à formulação de planos estaduais de ensino. Esta premissa levava à conclusão de que as autoridades estaduais de educação necessitavam treinamento específico para preparar e executar os planos estaduais de

\footnotetext{
${ }^{21}$ Ata da Reunião do Colegiado do Colégio Universitário da UFMG. Belo Horizonte, 18 de novembro de 1970. Arquivo do Centro Pedagógico da UFMG.
} 
ensino, o que legitimava o acordo assinado para que consultores norte-americanos pudessem assessorar e orientar, normativamente, este processo. ${ }^{22}$

Para o deputado federal pelo estado da Guanabara entre 1967 e 1968, Márcio Moreira Alves, conhecido como o "provocador do AI-5" por proferir um discurso convocando um boicote às comemorações do Dia da Independência do Brasil, o objetivo deste acordo foi "doutrinar professores" e "criar um núcleo de mandarins do ensino médio que, treinados nos Estados Unidos, possam pôr em prática em todos os Estados brasileiros e, desde, já, em alguns dos mais importantes, as diretrizes de planejamento norte-americano para o ensino secundário no Brasil" (ALVES, 1968, p. 64). De fato, a legitimação de uma "transformação modernizadora" que estava sendo imposta à nacionalidade brasileira passava pela internalização de uma filosofia pedagógica desenvolvida nos Estados Unidos. Segundo Arapiraca (1979, p. 151), "houve toda uma mobilização dos quadros da inteligentzia pedagógica brasileira no sentido de absorção das práticas educativas observadas nos EUA, principalmente com referência à efetividade e à eficiência do aparelho escolar alternativo para as minorias ali desenvolvido". Segundo o mesmo autor, "a postura acrítica de educadores colonizados" teria contribuído para a reprodução dos valores educacionais norte-americanos no aparelho escolar brasileiro a partir de uma nova racionalidade pedagógica.

Em seu livro autobiográfico, resultado da produção de seu memorial para o concurso de professora titular na UFMG em 1981, a professora Magda Soares analisou seu engajamento neste modelo educacional que foi comum a muitos outros professores da sua geração. Foi com perplexidade e, ao mesmo tempo, com consciência da presença e da força do conteúdo ideológico que a arrebatou que ela recordou "a outra" que foi e que se viu adepta de "uma tecnologia de ensino determinista, baseada em predição e controle" e lutando "por maior 'eficiência' e maior 'produtividade' do ensino e do sistema educacional" (SOARES, 1991, p. 80). Em 1966, na condição de diretora de ensino do Colégio Universitário da UFMG, a professora já havia realizado uma viagem aos Estados Unidos, financiada pela Fundação Ford, para "cumprir um amplo programa de análise dos métodos de linguística aplicada ao ensino de línguas estrangeiras, estudos sobre a instrução programada e métodos de preparação de livrostextos". ${ }^{23}$ Durante cinco semanas, a professora visitou, juntamente com a professora assistente Maria Lisboa de Oliveira, a Associação de Pesquisas Científicas de Chicago, a Universidade de Stanford e o Instituto de Linguística da Universidade de Michigan. De lá trouxe na bagagem livros e ideias que marcaram seu percurso profissional.

Embora as fundações norte-americanas, como a Ford, não fossem instrumentos do governo de seu país, pois atuavam com recursos próprios que garantiam a sua autonomia, suas ações em países estratégicos favoreciam a realização dos objetivos de governo dos Estados Unidos. Segundo Motta (2014, p.142), "agradava ao governo dos Estados Unidos que as fundações privadas estivessem disseminando conceitos e perspectivas teóricas alternativas ao marxismo e levando mais intelectuais brasileiros aos Estados Unidos para conhecer sua sociedade e seus valores". De fato, em sua entrevista para esta pesquisa, a professora Magda Soares afirmou que sua viagem ao país norte-americano em 1966 não foi uma iniciativa dela, mas de um "grupo que veio conhecer a universidade, visitou vários institutos e quando esteve no Colégio Universitário fez esse convite para essa visita lá, para conhecer as coisas lá" e reconheceu que "foi aquela coisa dos Estados Unidos que querem captar a gente o mais possível". ${ }^{24}$

No início da década de 1970, ao mesmo tempo em que o país vivia uma "euforia" decorrente do crescimento econômico, experimentava também uma fase de violenta repressão do Estado aos intelectuais de esquerda e às lideranças estudantis, camponesas e operárias que

${ }^{22}$ Convênio entre o MEC através da DES, o CONTAPE e a USAID/BRASIL. In: ALVES, M. M. O Beabá dos MEC-USAID. Rio de Janeiro: Gernasa, 1968.

${ }^{23}$ Diretora do Colégio Universitário da UFMG nos Estados Unidos. Diário de Notícias, 1/10/1966, edição 13.457.

${ }^{24}$ Magda Soares. Belo Horizonte, 31 out. 2020 (Entrevista realizada por via remota para esta pesquisa). 
se engajavam na resistência e na oposição armada e já não lutavam por reformas de base, como a reforma educacional, mas por uma transformação estrutural do país. Desse modo, segundo Germano (1993), não teria existido espaço para a atuação dos grupos de pressão por um outro modelo de reforma do ensino, pois estes estavam desarticulados, incorporados a outras formas de luta ou mesmo destroçados pelo "Estado do terror". Ao contrário da reforma universitária de 1968, que foi marcada por numerosas manifestações estudantis que reivindicavam o aumento de verbas e de vagas para as universidades públicas, a reforma do ensino de $1^{\circ}$ e $2^{\circ}$ graus de 1971 aconteceu em um contexto de recrudescimento do aparato repressivo policial e militar.

Além disso, o clima entre os educadores era de grande expectativa e a reforma foi recebida entusiasticamente pela maioria dos docentes e até pelos deputados da oposição. $\mathrm{O}$ professor Francisco das Chagas Pereira, um dos educadores convidados pelo MEC para compor uma espécie de escalão precursor para a implantação da lei 5.692/71, afirmou em depoimento registrado na Câmara dos Deputados em 1985 que "estávamos, na época, todos possuídos de messianismo" (PEREIRA, 1985, p. 113), se referindo ao processo não apenas de adesão dos professores à reforma, mas de mobilização a seu favor. Em suas memórias, escritas em 1981, Magda Soares também observou que a ideologia em curso exerceu grande dominação sobre ela: "recordo minha vida acadêmica e vejo-me (vejo-a) solidária ao modelo educacional que se procurava construir e, mais que isso, participante, eu (ela) também à cata de eficiência e eficácia, de racionalização, operacionalização e produtividade" (SOARES, 1991, p. 82).

Estes profissionais foram recrutados em diferentes pontos do país com o objetivo de dar suporte técnico à elaboração de mudanças que foram definidas pelo poder dominante, quase não sendo necessária a participação de políticos (GARCIA, 1984). Até o deputado Laerte Viera, que era líder da oposição, declarou à época que "o projeto teria aprovação pacífica entre todos nós" (apud GERMANO, 1993, p. 160). Vale lembrar que o Congresso já havia sido fechado pelos militares em 1966 e 1968 por se contrapor às determinações do regime e, além disso, o país vivia em plena vigência do AI-5.

O pensamento tecnicista advindo do universo empresarial que invadiu o pensamento educacional, portanto, não teve resistência intelectual nem política para reordenar todo o processo educativo e se manifestou tanto na organização hierárquica do sistema escolar supervisores, orientadores educacionais, administradores, inspetores -, quanto numa pedagogia na qual o professor e os estudantes seriam meros executores de ações cuja concepção, planejamento, coordenação e controle ficavam a cargo de especialistas supostamente habilitados, neutros e imparciais (SAVIANI, 1999; LIRA, 2010). Além disso, ao organizar a educação com base em sua política de desenvolvimento econômico, o Estado enfatizou o papel da escolarização como fator de desenvolvimento e de integração nacional e a assumiu como parte de seu aparelho ideológico. A lei 5692/71 foi considerada a ferramenta mais importante do governo civil-militar para consolidar a ideologia de eficiência, eficácia e funcionalidade do sistema de ensino (CORRÊA, 2012)

E foi em um clima de confiança, mas também de medo, que se instituiu o GT formado para "estudar, planejar e propor medidas para atualização e expansão do ensino fundamental e do colegial" pelo então presidente General Emilio Garrastazu Médici. Por meio de um decreto, ele estabeleceu que o GT seria composto por nove membros que seriam designados pelo Ministro da Educação e Cultura e que teriam o prazo de sessenta dias para a conclusão dos trabalhos. ${ }^{25}$ Entre 15 de junho e 14 de agosto de 1970, o GT trabalhou na Faculdade de

\footnotetext{
${ }^{25}$ O Coronel Jarbas Passarinho, então ministro da Educação e Cultura, designou, além de Magda Soares (professora da UFMG), o padre José de Vasconcellos (membro do Conselho Federal de Educação), as professoras Eurípedes Brito da Silva (diretora do Ensino Secundário do MEC), Aparecida Jolly Gouveia (pesquisadora do INEP), Raimundo Valnir Cavalcanti Chagas (membro do Conselho Federal de Educação e professor da UFCE), Aderbal de Araújo Jurema (professor da UnB), Clélia de Freitas Capanema (presidente do Conselho Federal de Educação do Distrito Federal), Geraldo Bastos (técnico de Educação do MEC) e Gildásio Amado (professor do Colégio Pedro II).
} 
Educação da UnB e produziu um relatório de suas atividades e um anteprojeto de lei. A participação da professora Magda Soares neste GT foi também uma indicação do reitor da UnB, o mineiro Caio Benjamin Dias. Embora ela tenha avaliado positivamente tanto o grupo, quanto a condução dos trabalhos pelo Coronel Jarbas Passarinho, reconheceu certa contradição nessa colaboração, conforme relatou em entrevista:

Então formaram um grupo que foi um grupo bom, sabe? Eu fiquei muito... porque eu era aqui da esquerda, das passeatas e não sei o quê... então o meu grupo dizia: "Você vai colaborar? Você vai pra lá colaborar com essa gente?”. Aí, nós na Faculdade de Educação, na pósgraduação, nós tínhamos um grupo menor que tinha uma filosofia assim: "Nós temos que aproveitar as brechas". Tanto é que criamos um jornalzinho que chamava "A Brecha". Que assim, deu uma brecha, a gente se mete para ver o que é que pode fazer, né? Eu discutindo com o grupo, aí falaram: "Essa é a brecha! Você vai". ${ }^{26}$

A professora Magda Soares já havia participado, em 1968, quando as manifestações estudantis explodiram nas grandes cidades brasileiras reivindicando o aumento de verbas e vagas nas universidades públicas, de um GT que foi constituído pela direção do partido Aliança Renovadora Nacional (ARENA), em Minas Gerais, "para estudar o problema universitário brasileiro e elaborar sugestões que possam auxiliar o Governo Federal". ${ }^{27}$ Embora a nota da ARENA na qual foi divulgada a constituição do GT tenha enfatizado que "a comissão é apolítica, sem nenhuma vinculação ao partido", ${ }^{28}$ a iniciativa foi uma ação estratégica para atenuar as críticas em relação à ausência de participação de professores e estudantes na elaboração da reforma universitária que estava em curso. O GT constituído pela Arena contou com o apoio da Federação das Indústrias de Minas Gerais que manifestou em nota oficial apoio irrestrito ao governo civil-militar afirmando que "o empresariado está pronto para oferecer ao Governo a colaboração necessária para assegurar ao País 'a tranquilidade que reclama o árduo trabalho de revitalização nacional" e que "é importante a participação dos jovens no processo de desenvolvimento, mas a intranquilidade não interessa a ninguém e prejudica a todos, daí ficar implícita a disposição do empresários de colaborar com o Governo para que o país se conserve em normalidade". ${ }^{29}$

O GT constituído para elaborar o anteprojeto da Reforma de Ensino em 1970 não era, entretanto, o primeiro Grupo de Trabalho constituído com a mesma finalidade. Um ano antes, outro grupo formado por educadores e pesquisadores do Instituto Nacional de Estudos Pedagógicos (INEP) já tinha apresentado projetos fundamentados que foram amplamente divulgados e remetidos para análise e apresentação de sugestões dos Conselhos Estaduais de Educação, das Secretarias de Educação e das entidades representativas de professores e escolas públicas e particulares. ${ }^{30}$ As

\footnotetext{
${ }^{26}$ Magda Soares. Belo Horizonte, 31 out. 2020 (Entrevista realizada por via remota para esta pesquisa).

27 Além da professora Magda Soares, também foram inicialmente convidados para este grupo os professores Amílcar Viana Martins, Celso Cordeiro Machado, Eduardo Cisalpino, Hilton Rocha, Orlando Carvalho, Jaime Ferreira da Silva, José Faria Tavares, José Lins Mesquisa, Leônidas Machado Magalhães, Luís de Paula Castro, Rui Lourenço Filho e Giovanin Zazzineli, além dos estudantes universitários Tomás Boardman, João Maciel e Alberto Advíncula Reis, nenhum dos três representantes das entidades estudantis. Ainda assim, os universitários destacados não aceitaram a convocação sob o argumento de que não acreditavam nos objetivos da comissão (Arena quer presença estudantil. Jornal do Brasil, Rio de Janeiro, quarta-feira, 17 de julho de 1968, p. 15).

${ }^{28}$ Arena de Minas cria seu GT para a universidade. Correio da Manhã, Rio de Janeiro, 7 de julho de 1968, p.1.

${ }^{29}$ Empresariado mineiro oferece ajuda para criar clima de tranquilidade. Jornal do Brasil, Rio de Janeiro, sábado, 6 de julho de 1968, p. 7.

${ }^{30}$ Decreto $\mathrm{n}^{\circ}$ 65.189, de 18 de setembro de 1969. Cria Grupo de Trabalho para propor a reforma do ensino fundamental. Legislação Informatizada da Câmara dos Deputados.
} 
concepções contidas ali também influenciaram a organização do Colégio Integrado do Centro Pedagógico, conforme veremos. Mas o governo federal acabou não endossando aqueles projetos. De acordo com Soares (1991), ao revisar os documentos e confrontar as propostas elaboradas pelo primeiro GT com as críticas que foram feitas a elas pelo segundo grupo, é possível identificar o conflito de ideologias e compreender porque tinham sido recusadas:

Os projetos refletem, ainda àquela época, a ideologia liberalpragmática do progressivismo (entre os membros daquele primeiro Grupo); as sugestões e críticas partem da nova ideologia da educação a serviço do desenvolvimento, expressa nos conceitos de maior rendimento, mais eficiência e produtividade, e na apresentação de sugestões para sua aplicação no sistema de ensino. Aliás, hoje compreendo por que o Governo Federal, que criara o primeiro Grupo, não aceitou os projetos por ele propostos e criou outro Grupo para elaborar novo projeto: o que tinha sido proposto não correspondia à ideologia dominante (SOARES, 1991, p. 85-86).

Daí se configurar ainda mais clara a afinidade do Grupo de Trabalho de $1970 \mathrm{com}$ as concepções educacionais pretendidas pelo governo civil-militar, uma vez que o anteprojeto foi bem acolhido pelo Ministério da Educação e sua tramitação e aprovação pelo Congresso foi rápida e pacífica. Por isso Magda Soares observou, dez anos após a lei no 5.692/71, que "hoje compreendo ainda que nós, o novo Grupo de Trabalho, captamos essa ideologia, ideologia que certamente já tínhamos, nós também, interiorizado" (SOARES, 1991, p. 86).

O Relatório Final do Grupo de Trabalho da Reforma de Ensino de $1^{\circ}$ e $2^{\circ}$ graus constituído em 1970 traduziu as discussões que estavam sendo realizadas desde meados da década de 1960. A proposta se adequou aos interesses de um mercado que demandava mão-deobra minimamente qualificada e barata ao propor que todos deveriam "chegar à idade adulta com algum preparo para o trabalho ou, pelo menos, uma opção de estudos claramente definida". Nesse sentido, o relatório apontava para a dualidade presente no ensino de $2^{\circ}$ grau que, em equilíbrio, seria "indispensável à formação regular" dos estudantes, qual seja,

uma escola supostamente orientada para o prosseguimento dos estudos - secundária - ao lado de outra, que com esta não se comunica voltada pretensamente para a vida - a profissional. Ambas ministram cursos de duração única estabelecida de fora; e a diferença entre elas é marcada pela exclusividade da formação geral na primeira e especializada na segunda. Acontece, porém, que ambas as características são indispensáveis em toda a escolarização regular, determinando-se in concreto a predominância de uma sobre a outra (RELATÓRIO, 1971 apud AGUIAR, 1975, p. 31).

Identificamos as principais características da reforma do $2^{\circ}$ grau proposta por este GT que foram, em certa medida, antecipadas pela experiência do Colégio Integrado do Centro Pedagógico da UFMG, em 1971. Elas podem ser sintetizadas pelos princípios de integração e flexibilização que, se adequadamente implementados, poderiam garantir uma organização escolar renovada. A ideia de integração se fez presente não apenas entre os níveis de ensino, mas entre as áreas de estudo e as disciplinas. A flexibilização se fazia notar da diversidade de currículos e de metodologias de ensino com o objetivo de se adaptarem aos interesses e aptidões dos estudantes - incluindo aí a possibilidade da continuidade dos estudos em nível superior ou 
sua terminalidade com uma habilitação profissional - bem como à capacidade das instituições de ensino e ao nível socioeconômico da região na qual estivesse inserida.

Este conjunto de princípios desenvolvidos no relatório do GT, entre outros, norteou a elaboração do anteprojeto de lei que foi, inicialmente, submetido à apreciação do Conselho Federal de Educação e, depois, aos conselhos estaduais de educação. A aparente horizontalidade das discussões, entretanto, não escondeu os procedimentos autoritários adotados pelo MEC. Cunha (2014), que analisou os anais da IV Conferência Nacional de Educação, de junho de 1969, e do seminário preparatório, de fevereiro de 1970, deduz que os debatedores contrários à profissionalização universal e compulsório do ensino de $2^{\circ}$ grau eram mais numerosos, que eles condenavam a especialização precoce na formação profissional, que reconheciam a importância da função propedêutica do ensino médio, e que a V Conferência Nacional de Educação que estava prevista teria sido suspensa por ordem do ministro da educação (CUNHA, 2014, p. 918).

Na condição de ministro da Educação, o Coronel Jarbas Passarinho também realizou modificações no documento, segundo ele "para manter a coerência geral da proposição e ajustála à política geral do governo" (PASSARINHO, 1981, p. 820). As alterações realizadas nessas oportunidades não chegaram a modificar aqueles princípios e, principalmente, não mudaram a concepção do ensino de $2^{\circ}$ grau. As consultas realizadas mantiveram a fórmula expressa na alínea "a" do parágrafo $2^{\circ}$ do artigo $5^{\circ}$ do anteprojeto que estabelecia que a parte de formação especial do currículo de $2^{\circ}$ grau teria o objetivo de habilitação profissional ou aprofundamento de determinados estudos gerais. Na sua Exposição de Motivos, o próprio ministro Coronel Passarinho destacou essa característica quando afirmou que "não há mais lugar, no Brasil de hoje, para o dualismo de uma escola média que leva à Universidade e outra que prepara para a vida. A escola é uma só e deve sempre cumprir essas duas funções indispensáveis a uma educação verdadeiramente integral" (PASSARINHO, 1981, p. 820).

A alteração que tornou a profissionalização obrigatória no ensino de $2^{\circ}$ grau se deu nas emendas assinadas pelos parlamentares na tramitação do projeto. Por exemplo, uma emenda do senador Antônio Carlos, outra do senador José Lindoso e outra assinada por oito deputados da bancada federal de São Paulo solicitavam que fosse excluído da referida alínea "a" do parágrafo $2^{\circ}$ do artigo $5^{\circ}$ a frase "ou aprofundamento em determinadas ordens de estudos gerais". Nas justificativas dessas emendas parlamentares argumentou-se que aquela frase, de "maneira sutil e argilosa" abriria caminho "para a manutenção daquilo que, justamente, o projeto visa a extirpar: a educação descompromissada com a vida individual e com o futuro do país" (apud SAVIANI, 1986, p. 147) e que, mantida aquela opção, "certamente estimularia a manutenção dos cursos "clássicos' e 'científicos"” e frustraria os legisladores (apud SAVIANI, 1986, p. 146). Mas foi uma emenda de autoria do deputado Bezerra de Melo que prevaleceu no projeto e contou com a seguinte justificativa:

Toda a filosofia do projeto está voltada para as necessidades do desenvolvimento que dia a dia exige mais técnicos de nível médio para a empresa privada e para a empresa pública. É necessário fechar, de uma vez por todas, a porta das escolas acostumadas ao ensino verbalístico e academizante, que não forma nem para o trabalho nem para a vida. A alternativa "ou aprofundamento em determinadas ordens de estudos gerais" seria, sem dúvida, a grande brecha por onde resvalariam as escolas e os sistemas avessos à formação profissional do jovem (apud SAVIANI, 1986, p. 147).

Por esta razão Cury et ali (1982) afirmaram que "apesar das críticas existentes sobre o caráter tecnicista da lei 5.692/71, o Grupo de Trabalho formado para a sua proposição não pode 
ser responsabilizado por esse engano, mesmo porque seu projeto inicial foi alterado" (CURY et ali, 1982, p. 9). Para Saviani (1986), diferentemente, ao tornar a profissionalização obrigatória no ensino de $2^{\circ}$ grau, os parlamentares apenas preservaram o espírito que já estava presente no anteprojeto e que poderia ser contradito por aquela frase, visto que ao se referir à profissionalização na educação então vigente o documento do GT afirmava que se tratava de uma exceção e que "o caminho a trilhar não é outro senão o de converter a exceção em regra, fazendo que o segundo grau sempre se conclua por uma formação específica" (apud SAVIANI, 1988, p. 149). Essa percepção foi compartilhada por Magda Soares, integrantes do GT responsável pelo anteprojeto, como vimos.

De fato, se recuperarmos as concepções de educação que estavam presentes entre os educadores que participaram da elaboração do anteprojeto vamos encontrar posições como a do educador Valnir Chagas que aceitava muito naturalmente que a reforma fosse efeito de causas econômicas e não o contrário. Segundo ele, a nova lei "atualiza a estrutura escolar em relação às mudanças operadas na economia, nas finanças, na previdência e na administração pública" (apud GARCIA, 1980, p. 227). O relatório do GT constituído para propor o projeto de lei da reforma universitária já antevia a necessidade de uma reforma do ensino médio que pudesse preparar o estudante para o trabalho e, com isso, fizesse diminuir a demanda de vagas nas instituições de ensino superior. A profissionalização em nível de $2^{\circ}$ grau foi tomada como uma resposta àquelas reivindicações estudantis por mais verbas e vagas nas universidades, pois atenuaria a demanda pelo ensino superior com a possibilidade de terminalidade dos estudos em nível médio, ao mesmo tempo em que legitimaria a diminuição dos investimentos públicos nas universidades. Para Cunha (2014, p. 920), entretanto, a demanda por técnicos de nível médio era uma crença sem respaldo estatístico, pois "ninguém conhecia o volume de oportunidades ocupacionais disponíveis, apenas acreditava-se que ela fosse grande o suficiente para compensar, minimamente, os concluintes do ensino médio que não ingressassem nos cursos superiores" e essa crença bastava.

Consideramos, entretanto, que aquela "formação específica" de que tratava o anteprojeto e que criava condições para a terminalidade dos estudos no nível médio não poderia ser reduzida à obrigatoriedade da profissionalização prevista na lei ${ }^{\circ} 5.692 / 71$, visto que outras possibilidades de formação poderiam ser abertas. A experiência do Colégio Integrado do Centro Pedagógico da UFMG indicava algumas dessas possibilidades de organização curricular que poderiam advir da simples manutenção daquela frase - "ou aprofundamento em determinadas ordens de estudos gerais" - na redação final da lei.

\section{A experiência do Colégio Integrado do Centro Pedagógico da UFMG}

Se, por um lado, o Colégio Integrado do Centro Pedagógico da UFMG não escapou daquela concepção tecnicista de educação vigente em sua época, por outro não se reduziu a ela. A proposta deste colégio foi testar uma organização e um currículo que permitisse ao estudante realizar estudos de nível e naturezas diferentes, de acordo com suas aptidões, interesses e habilidades, independentemente de áreas ou seriação. Para tanto, o curso ofereceu um elenco de disciplinas semestrais e a cada estudante foi permitido compor o seu currículo da maneira que desejasse, escolhendo, dentre as disciplinas oferecidas, quantas e quais quisesse cursar no semestre. Este aspecto da organização escolar apostou no respeito à individualidade e à autonomia de cada estudante que, embora pudesse contar com um professor-conselheiro para o ajudar a compor o seu currículo, deixava o caminho à escolha do aluno.

O currículo do Colégio Integrado era composto por três conjuntos de disciplinas: área básica, área de opção e área de expansão. As disciplinas da área básica eram aquelas consideradas necessárias para todos os cidadãos em formação e que proporcionariam uma boa educação geral acadêmica. Além das disciplinas de História Moderna e Contemporânea e 
História do Brasil, por exemplo, constaram no currículo outras como Estudo do Meio e dos Recursos Naturais, Organização e Aproveitamento do Espaço Geográfico, Biologia Básica, Física Básica e Química Básica, Introdução à Matemática Moderna e Estudo das Funções Elementares, Redação, Introdução à Literatura e Comunicação. Note-se que as matérias da área básica não correspondiam aos componentes curriculares tradicionais, mas se aproximavam dos recortes efetuados nas disciplinas da graduação, o que já representava uma tentativa de integrar um e outro nível de ensino.

As disciplinas da área de opção foram voltadas para o desenvolvimento dos interesses e das aptidões individuais dos estudantes. Constaram aí matérias como Evolução Econômica do Brasil, Análise Interpretativa do Homem Contemporâneo, Quadro Natural e o Problema Econômico das Grandes Potências, Introdução à Antropologia Filosófica, Estudo Comparativo de Animais e Vegetais Sob o Ponto de Vista Reprodutivo, Introdução aos Mecanismos de Reações Orgânicas, Introdução ao Cálculo, Probabilidade Estatística, Desenho Geométrico I e II, Desenho Projetivo I e II, História da Língua Portuguesa, Análise e Composição Literárias, O Romance de José Lins do Rego, O Romance de Clarisse Lispector, entre outras.

As disciplinas da área de expansão pretenderam desenvolver habilidades de natureza motora, artística ou profissionalizante. Daí que a "formação específica" oferecida não se restringia à profissionalização, o que fica evidente nas disciplinas ofertadas: Prática de Teatro, Cinema I e II, História da Arte, Arte no Século XX, Arte no Brasil, Atelier Livre, Apreciação Musical, Música Brasileira, Basquete, Futebol de Salão, Danças Femininas, Handebol, Ginástica, Vôlei, Elementos de Cartografia, Fundamentos de Aerofotogrametria, Datilografia, Encadernação, Perfurações de Cartões, Operação de Computador, Programação de Computador, Introdução ao Jornalismo I e II. Valorizou-se aqui a educação artística e o desenvolvimento de recursos de apreciação para promover a capacidade de usufruir os bens da cultura.

Esta organização curricular se aproximou daquilo que foi proposto pelo primeiro GT da reforma de ensino, em 1969, que previa que a educação de grau médio "destina-se à formação geral e à formação profissional do adolescente, além de ser propedêutica ao ensino de grau superior". Este GT previu em seu relatório que em cada curso deveriam constar "disciplinas e práticas educativas obrigatórias e optativas", bem como "atividades complementares de formação artística e científica". Ao ensino médio de formação geral estaria garantida uma "variedade de currículos com o fim de proporcionar áreas de estudo diferenciadas (...) que atenderão a aptidões e interesses dos alunos para estudos literários, científicos, econômicos, sociais e artísticos", sendo "facultada a inclusão de opções técnicas". ${ }^{31}$ Tudo indica que a Comissão Especial de Planejamento do Colégio Integrado do Centro Pedagógico da UFMG esteve atenta às perspectivas que orientariam a reforma com o objetivo de antecipá-la.

A cada semestre, os estudantes do Colégio Integrado poderiam compor o seu currículo com a inclusão de disciplinas de cada uma das três áreas (ver Tabela 1). Esta composição foi feita levando-se em conta o número de créditos que o estudante era capaz de fazer por semestre e o número de semestres em que ele pretendia fazer seu curso (entre 4 a 10 semestres). As disciplinas da área básica foram ofertadas nos dois semestres da experiência, de manhã e à tarde. As disciplinas das áreas de opção e expansão variaram a cada semestre e algumas foram oferecidas só de manhã, outras só à tarde. Os estudantes puderam escolher cursar as disciplinas só de manhã, só à tarde ou de manhã e à tarde. O horário foi organizado em módulo e cada módulo equivalia a 30 minutos. Havia aulas de 2 módulos até 5 módulos. Cada turno era composto de 10 módulos, sendo que o recreio, que acontecia entre o $5^{\circ}$ e o $7^{\circ}$ módulos, era também contabilizado na carga horária. Contrariando a rotina de programas e horários rígidos da escola tradicional, essa flexibilidade de programas e horários pretendeu atender as condições próprias dos estudantes, bem como ao ritmo de trabalho de cada um.

${ }^{31}$ Relatório Final do Grupo de Trabalho para propor a Reforma do Ensino Médio e Primário. Rio de Janeiro, MEC, 1969. Arquivo Histórico do INEP. Atom-INEP. 
Cada disciplina era valorizada por créditos correspondentes à sua carga horária. A cada 15 horas era computado 1 crédito, sendo 60 horas de aula (ou 4 horas de aula por semana) equivalente a 4 créditos. A carga horária total do curso era de 2200 horas e o estudante poderia cumpri-la em, no mínimo, 4 semestres e, no máximo, 10 semestres. Durante esse tempo, o estudante deveria obter pelo menos 147 créditos para a obtenção do diploma. A verificação do rendimento escolar era feita pela avaliação da aprendizagem e a apuração da frequência. A avaliação da aprendizagem foi feita pelo sistema de pontos cumulativos. A cada semestre, que era dividido em dois períodos, eram distribuídos 100 pontos em cada disciplina. Cada instrumento de avaliação (provas, exercícios, pesquisas, relatórios) não poderia distribuir mais que 40 pontos. O estudante estava aprovado se obtivesse um mínimo de 60 pontos, desde que tivesse frequência superior a $75 \%$ em cada disciplina. Também estava prevista uma recuperação para o estudante que acumulou entre 40 e 60 pontos.

Este modelo de funcionamento do Colégio Integrado contava com reuniões semanais entre o corpo docente, que precisava estar consciente dos objetivos propostos. Os professores do antigo Colégio Universitário foram aí aproveitados. Esse grupo de professores foi considerado "o que havia de melhor no ensino médio em Belo Horizonte por sua constante renovação didática, seu entrosamento com os alunos e sua renovação de conteúdo" (GUIA, 1971). Ele era composto, em sua maioria, por professores do sexo masculino, numa faixa etária entre 25 e 50 anos, cuja situação funcional era a de professor assistente em regime de 24 horas semanais e lotação em unidades do ensino superior.

A formação do corpo discente do Colégio Integrado deveria constituir um grupo heterogêneo que fosse representativo do universo de alunos de nível colegial da comunidade. Para a constituição deste grupo, duas variáveis deveriam ser consideradas: o nível de "habilidade intelectual" e o nível socioeconômico. A seleção das primeiras turmas, entretanto, levou em conta apenas a primeira variável, uma vez que para ela se dispunha de instrumentos capazes de mensurar o aproveitamento dos estudantes nas matérias. Não havia, ainda, um questionário que permitisse determinar precisamente o nível socioeconômico dos estudantes, conforme se argumentava (GUIA, 1971). Planejava-se a preparação de um questionário por uma equipe de pesquisadores que seria aplicado a todos os candidatos "para que seus itens pudessem sofrer um tratamento estatístico que determinasse sua validade". Os procedimentos adotados, entretanto, parecem revelar certa desconfiança em relação à adoção da variável socioeconômica, uma vez que se pretendia atestar, primeiramente, a existência de uma correlação entre o "nível intelectual" e o nível socioeconômico para avaliar a importância da segunda variável para a seleção de futuros alunos.

Administrativamente, o Colégio Integrado do Centro Pedagógico manteve uma Coordenadoria de Curso e os Setores de Ensino. À Coordenadoria estavam ligados a biblioteca, a cantina, a secretaria geral de ensino, o Centro Audiovisual, a mecanografia e a oficina. Os Setores de Ensino somavam dez, a saber, o Setor de Português, o Setor de Línguas Estrangeiras, o Setor de Matemática, o Setor de Desenho, o Setor de História, o Setor de Geografia, o Setor de Filosofia, o Setor de Física, o Setor de Química e o Setor de Biologia. Havia laboratórios para os setores de Biologia, Física, Química e Línguas que funcionavam para as aulas práticas e para atender aos alunos que dele necessitassem. Para isso, contavam sempre com a presença do auxiliar de laboratório, de um estagiário ou mesmo do professor. Já o laboratório de Arte funcionava junto ao Setor de Desenho e aí eram desenvolvidas atividades artísticas dos estudantes matriculados na disciplina Atelier Livre.

O Colegiado era o órgão superior dentro do Colégio Integrado e estava constituído pela Coordenadoria do Curso e por um representante de cada Setor de Ensino. Havia, ainda, uma Assessoria de Ensino que foi criada pelo Conselho Deliberativo do Centro Pedagógico com o objetivo de assumir, junto com a Coordenadoria de Curso, as responsabilidades e a orientação pedagógica do Colégio Integrado. Também um Centro de Orientação que proporcionava 
atendimento aos estudantes com dificuldades de aprendizagem, problemas pessoais, dificuldades disciplinares e orientação vocacional. Além disso, contava com um Centro de Audiovisual responsável pelo controle das atividades relacionadas à utilização de recursos audiovisuais. O Colégio Integrado do Centro Pedagógico manteve do Colégio Universitário o Centro Estudantil Aluísio Pimenta (CEAP), órgão de representação estudantil que homenageava o ex-reitor.

Terminado o primeiro semestre desta experiência, os estudantes foram consultados por meio de um questionário sobre o funcionamento das atividades do Colégio Integrado. $\mathrm{O}$ objetivo, segundo o relatório produzido pela escola, era adequar-se de maneira mais eficiente às necessidades de seu corpo discente e, ao mesmo tempo, corrigir possíveis falhas. Concomitantemente, entre 29 de junho e 29 de julho de 1971, o projeto de lei da reforma do ensino tramitava no Congresso Nacional onde, por meio das emendas parlamentares, tornaria inviável a manutenção daquela experiência.

A análise dos questionários mostrou que os estudantes consideraram que os trabalhos para casa foram "excessivos e apertados" nas disciplinas da área básica e "razoáveis e folgados" nas áreas de opção e de expansão. Os métodos de ensino e o material didático utilizado pelos professores nas aulas foram considerados "interessantes e atuais" e o processo de avaliação foi aprovado pela maioria. O sistema de plantão previsto na organização do Colégio Integrado e que garantia um atendimento quase permanente dos estudantes pelos professores foi raramente utilizado, sendo que quando o faziam recebiam a assistência necessária, conforme consta na avaliação. Os estudantes ainda aprovaram o regime disciplinar e o tipo de currículo, não seriado e por sistema de crédito. Embora fossem os próprios estudantes responsáveis por escolher as disciplinas cursadas a cada semestre, a distribuição da carga horária foi avaliada como "pesada" por alguns. O sistema administrativo, que contava com cantina, secretaria, biblioteca, centro de orientação, assessoria de ensino e diretoria, foi considerado adequado para o cumprimento dos objetivos didáticos e pedagógicos do Colégio. Em síntese, segundo o relatório, os estudantes avaliaram a experiência do Colégio Integrado como "útil" e "positiva", mas apresentaram alguma dificuldade de adaptação às suas diferenças de horário, métodos de ensino, regime disciplinar e currículo (GUIA, 1971).

A intenção dos professores era aplicar o mesmo questionário, com as reformulações devidas, também ao final do $2^{\circ}$ semestre com o intuito de realizar uma análise comparativa. Entretanto, na época de sua aplicação os estudantes já tinham tomado conhecimento de que a experiência do Colégio Integrado não teria prosseguimento e que a situação escolar de cada um ainda não estava definida, o que, segundo o mesmo relatório, não favoreceu as condições necessárias para realizar o levantamento da opinião dos estudantes sobre o curso nos dois semestres. Com a descontinuidade do Colégio Integrado, as matrículas dos estudantes foram transferidas para o Colégio Técnico da instituição. ${ }^{32}$

Como outras experiências do período, o Colégio Integrado procurou trabalhar na base da cooperação, do desenvolvimento da noção de responsabilidade e da disciplina voluntária. Em uma avaliação selecionada para compor a publicação da escola - que não retrata, necessariamente, a impressão geral dos estudantes, mas dá a dimensão dos valores que o colégio procurou difundir - uma das alunas observou que no Colégio Integrado "não há rigor, há amizade; não há vigilância, há liberdade; não há brigas, há bate-papos; não há sermões, há troca de ideias; não há distinção (sr., nada disso); não há grupinhos, há todo mundo; não há fofocas, há lugar e hora para discutir os problemas" (GUIA, 1971).

Ao encontro desta avaliação, os responsáveis pelo relatório de avaliação das atividades do Colégio Integrado concluíram que "um espírito de camaradagem, de sociabilidade, de

\footnotetext{
${ }^{32}$ Magda Soares. Belo Horizonte, 31 out. 2020 (Entrevista realizada por via remota para esta pesquisa).
} 
solidariedade foi-se criando entre alunos e o corpo administrativo". Até a confirmação da notícia de que a experiência não teria continuidade, a avaliação era a seguinte:

Consideramos que o clima que existia até outubro no colégio era realmente uma das coisas mais fascinantes da experiência, embora para muitos pais, professores e mesmo alunos, havia uma certa exorbitância na liberdade reinante. Os fatos, no entanto, nos mostram que o que houve por parte de alguns alunos foi um deslumbramento com a liberdade adquirida, com o poder de decidir sobre a própria vida, de criar e com o direito adquirido de errar e poder assumir seu próprio processo. Direito esse que nas nossas escolas infelizmente não é dado ao adolescente. Podemos quase afirmar tranquilamente que os casos de 'indisciplina' eram provenientes de alunos de formação mais rígida aos quais era dado, talvez pela primeira vez, o direito de se auto explorar, se auto testar, se auto avaliar (GUIA, 1971).

Considerando que essa impressão do Colégio como um lugar de exercício da liberdade e do respeito mútuo era compartilhada pelo corpo discente e administrativo, não deve causar estranheza que sua experiência tenha sido tão curta - como também o foram as experiências do CEAM, no Rio de Janeiro, e no CIEM-UnB, em Brasília - no contexto de opressão e controle que caracterizou a concepção escolar durante a ditadura civil-militar.

Tabela 1 - Disciplinas do Colégio Integrado do Centro Pedagógico por área e matéria (1971)

\begin{tabular}{|c|c|c|c|}
\hline & Área Básica & Área de Opção & Área de Expansão \\
\hline Arte & & & $\begin{array}{l}\text { Prática de Teatro } \\
\text { Cinema I } \\
\text { Cinema II } \\
\text { História da Arte } \\
\text { Arte no século XX } \\
\text { Arte no Brasil } \\
\text { Atelier livre } \\
\text { Apreciação musical } \\
\text { Música brasileira }\end{array}$ \\
\hline Biologia & $\begin{array}{l}\text { Biologia Básica I } \\
\text { Biologia Básica II }\end{array}$ & $\begin{array}{l}\text { Estudo comparativo de animais e vegetais sob o ponto de } \\
\text { vista reprodutivo } \\
\text { Botânica Geral } \\
\text { Zoologia Geral }\end{array}$ & \\
\hline $\begin{array}{l}\text { Ciências } \\
\text { Humanas }\end{array}$ & & $\begin{array}{l}\text { Psicologia I } \\
\text { Introdução à antropologia filosófica } \\
\text { História da Ciência } \\
\text { As raízes da contestação no pensamento filosófico } \\
\text { moderno e contemporâneo } \\
\text { Ciência, técnica e humanismo } \\
\text { Princípios filosóficos das instituições políticas } \\
\text { contemporâneas } \\
\text { Filosofia da Arte } \\
\text { Análise interpretativa do homem contemporâneo } \\
\text { Introdução às ideias contemporâneas } \\
\text { Introdução às ideias sociais e políticas } \\
\text { Esboço para uma filosofia do desenvolvimento } \\
\text { Cultura e sociedade } \\
\text { Instituições sociais }\end{array}$ & \\
\hline Desenho & & $\begin{array}{l}\text { Desenho geométrico I } \\
\text { Desenho geométrico II } \\
\text { Desenho projetivo I } \\
\text { Desenho projetivo II } \\
\end{array}$ & \\
\hline
\end{tabular}




\begin{tabular}{|c|c|c|c|}
\hline $\begin{array}{l}\text { Educação } \\
\text { Física }\end{array}$ & & & $\begin{array}{l}\text { Basquetebol } \\
\text { Futebol de salão } \\
\text { Danças femininas } \\
\text { Handebol } \\
\text { Ginástica } \\
\text { Voleibol } \\
\end{array}$ \\
\hline Física & $\begin{array}{l}\text { Física Básica I } \\
\text { Física Básica II }\end{array}$ & $\begin{array}{l}\text { Ótica } \\
\text { Eletricidade }\end{array}$ & \\
\hline Geografia & $\begin{array}{l}\text { Estudo do meio e } \\
\text { dos recursos } \\
\text { naturais } \\
\text { Organização e } \\
\text { aproveitamento do } \\
\text { espaço geográfico }\end{array}$ & $\begin{array}{l}\text { O espaço geográfico brasileiro } \\
\text { Problemas regionais e expansão urbana no Brasil } \\
\text { Geografia natural } \\
\text { Quadro natural e o problema econômico das grandes } \\
\text { potências }\end{array}$ & $\begin{array}{l}\text { Elementos de cartografia } \\
\text { Fundamentos de } \\
\text { aerofotogrametria }\end{array}$ \\
\hline História & $\begin{array}{l}\text { História Moderna e } \\
\text { Contemporânea } \\
\text { História do Brasil }\end{array}$ & $\begin{array}{l}\text { História Antiga e Medieval } \\
\text { Século XX } \\
\text { Evolução Econômica do Brasil }\end{array}$ & \\
\hline $\begin{array}{c}\text { Línguas } \\
\text { estrangeiras }\end{array}$ & & $\begin{array}{l}\text { Francês } 1^{\circ} \text { ciclo } \\
\text { Francês } 2^{\circ} \text { ciclo } \\
\text { Francês avançado } \\
\text { Inglês básico } \\
\text { Inglês intermediário } \\
\text { Inglês avançado } \\
\text { Inglês técnico }\end{array}$ & \\
\hline Matemática & $\begin{array}{l}\text { Introdução à } \\
\text { Matemática } \\
\text { Moderna } \\
\text { Estudo das Funções } \\
\text { Elementares }\end{array}$ & $\begin{array}{l}\text { Álgebra Moderna e Linear } \\
\text { Matemática Finitas } \\
\text { Introdução ao Cálculo } \\
\text { Probabilidade e Estatística } \\
\text { Geometria Moderna } \\
\text { Matemáticas Gerais }\end{array}$ & \\
\hline $\begin{array}{c}\text { Moral e } \\
\text { Cívica }\end{array}$ & & $\begin{array}{l}\text { Análise interpretativa do homem contemporâneo } \\
\text { Introdução às ideias econômicas } \\
\text { Introdução às ideias sociais e políticas } \\
\text { Esboço para uma filosofia do desenvolvimento }\end{array}$ & \\
\hline Português & $\begin{array}{l}\text { Redação } \\
\text { Introdução à } \\
\text { Literatura } \\
\text { Comunicação }\end{array}$ & $\begin{array}{l}\text { Literatura I } \\
\text { Literatura II } \\
\text { Sintaxe } \\
\text { História da Língua Portuguesa } \\
\text { Análise e Composição Literárias } \\
\text { O Romance de José Lins do Rego } \\
\text { O Romance de Clarice Lispector } \\
\text { O Romance de Machado de Assis } \\
\text { A poesia concretista } \\
\text { A expressão do absurdo na moderna ficção brasileira } \\
\text { A expressão oral }\end{array}$ & \\
\hline Química & $\begin{array}{l}\text { Química Básica I } \\
\text { Química Básica II }\end{array}$ & $\begin{array}{l}\text { Química orgânica } \\
\text { Introdução aos mecanismos de reações orgânicas } \\
\text { Matéria, energia e vida } \\
\text { Energia e equilíbrio químico }\end{array}$ & \\
\hline Técnica & & & $\begin{array}{l}\text { Datilografia } \\
\text { Encadernação } \\
\text { Perfuração de cartões } \\
\text { Operação de computador } \\
\text { Programação de computador } \\
\text { Introdução ao Jornalismo I } \\
\text { Introdução ao Jornalismo II }\end{array}$ \\
\hline
\end{tabular}

\section{A experiência interrompida}

Durante todo o período de funcionamento do antigo Colégio Universitário da UFMG, os professores eram lotados nos respectivos departamentos de suas áreas de atuação. Alguns se dedicavam integralmente ao colégio, outros conciliavam sua carga horária didática e demais atividades entre o ensino básico e o superior. Por isso, quando, em agosto de 1970, eles foram 
informados de que o Conselho de Graduação da UFMG havia aprovado que os professores do Centro Pedagógico (incluindo, claro, os do Colégio Integrado) fícariam lotados no Departamento de Métodos e Técnicas de Ensino da Faculdade de Educação à disposição daquele Centro, ${ }^{33}$ o retorno da maioria dos professores às suas lotações de origem foi inevitável, pois acabou pesando a identificação com suas áreas de formação. Este aspecto interno da organização da universidade, embora não tenha sido o motivo da descontinuidade da experiência do Colégio Integrado, não pode ser menosprezado, uma vez que foi o prestígio e o engajamento desses professores na proposta do Colégio Universitário e, depois, na do Colégio Integrado, que garantiu sua continuidade por mais alguns anos após o reitorado de Aluísio Pimenta, seu patrono.

O Colégio Integrado foi uma tentativa frustrada daqueles docentes de se manterem trabalhando juntos e com autonomia quando a permanência do Colégio Universitário na estrutura da universidade ficou insustentável. Desde os primeiros anos havia na universidade muitos críticos ao Coluni, considerado elitista e oneroso. O ex-reitor Marcello de Vasconcellos Coelho, um dos executores da ideia de criação do Centro Pedagógico como integrador das atividades da educação básica na universidade, chegou a afirmar que

pegavam-se, no $3^{\circ}$ científico, os melhores alunos do [Colégio] Loyola, os melhores alunos do Santo Antônio, os melhores alunos do Municipal e os colocava aqui dentro com professores em tempo integral, uma média de três alunos por professor, quando na universidade você não tinha tempo integral. O orçamento do Colégio Universitário, para o $3^{\circ}$ ano, era muito maior, o dobro do da Faculdade de Letras. Nós achamos que isso era uma loucura (...). Eu considerava o Colégio Universitário um cursinho de luxo (COELHO, 1998, p. 114).

É o próprio Marcello Coelho que descarta qualquer influência dos militares para o fim do Colégio Universitário, afirmando que "não houve absolutamente nesse ponto um veto militar" (COELHO, 1998, p. 115). No caso do Colégio Integrado, que já estava inserido na estrutura do Centro Pedagógico, a descontinuidade se deu por outras razões.

No final do ano letivo de 1971, o diretor-geral do Centro Pedagógico, Eder José dos Santos, encaminhou para a aprovação do Conselho Estadual de Educação o Plano de Trabalho da instituição elaborado para o ano seguinte. Oficialmente, o CEE-MG não tinha competência para se pronunciar sobre a matéria, uma vez que não estava implicado no funcionamento de estabelecimentos de ensino pertencentes ao sistema federal, a não ser nos casos de cursos experimentais ou experiências pedagógicas. Como a lei 5692/71 já tinha sido aprovada com a obrigatoriedade da profissionalização no nível secundário, o Centro Pedagógico solicitava autorização para a continuidade do Colégio Integrado como uma experiência que "permitirá a avaliação da viabilidade de novas normas propostas [pela lei 5692/71] para o ensino de $2^{\circ}$ grau (currículo por oferta de cursos, matrícula por disciplinas, sistema de créditos etc.)". Além disso, justificava a ausência das disciplinas de formação profissional "por se encontrar ainda em fase de transição a fusão do Colégio Técnico com o Colégio Integrado, fuso que se concretizará a partir de $1^{\circ}$ de janeiro de 1972". E ainda ponderava que "aos atuais alunos do Colégio Integrado não seria exigida habilitação profissional, desde que iniciaram o curso no regime anterior". Por fim, prometia que “em 1972, o currículo do ensino de $2^{\circ}$ grau do Centro Pedagógico já incluirá a habilitação profissional” (MINAS GERAIS, 1971).

Embora o ofício do CP ao CEE-MG confirme não apenas o interesse, mas também as tentativas de dar continuidade à experiência do Colégio Integrado, o documento não sustenta

\footnotetext{
${ }^{33}$ Ata da Reunião do Colegiado do Colégio Universitário da UFMG. Belo Horizonte, 26 de agosto de 1970. Arquivo do Centro Pedagógico da UFMG.
} 
as razões que justificariam a necessidade de aprovação do Plano de Trabalho do Centro Pedagógico pelo Conselho Estadual de Educação de Minas Gerais. Uma vez que havia a promessa de incorporar as disciplinas necessárias à formação profissional obrigatória já no ano seguinte, o Colégio Integrado se tornaria um curso regular, ainda que fossem realizadas pesquisas sobre o seu funcionamento. Dessa forma, o parecer do CEE-MG orientava um posicionamento para o Centro Pedagógico com base na autonomia da universidade, que a dispensava de ter de solicitar a outro órgão autorização para o funcionamento do ensino de $1^{\circ} \mathrm{e}$ $2^{\circ}$ graus, em caráter regular, "visto que a unidade se integra naturalmente em sua estrutura e é indispensável ao cumprimento de seus próprios objetivos, quer como campo de pesquisa, quer como campo para a prática de ensino" (MINAS GERAIS, 1971).

$\mathrm{O}$ fato é que nunca houve uma fusão do Colégio Integrado com o Colégio Técnico. Se os estudantes do primeiro acabaram sendo transferidos para o segundo, cursaram um modelo de ensino que em nada lembrava aquela experiência que se pretendia inovadora. Ao contrário, o Colégio Técnico foi instituído em 1969 com o objetivo de manter cursos de formação de técnicos necessários à mão de obra de indústrias, de serviços de saúde e de laboratórios, de construção e manutenção de equipamentos eletrônicos e mecânicos. Sua implantação resultou de um convênio entre o governo brasileiro e o governo britânico e se adequou perfeitamente à lei da reforma do ensino aprovada no Congresso em 1971. Com um corpo docente qualificado e um aporte financeiro de peso, o COLTEC se tornou uma escola-referência da concepção tecnicista de educação imposta pela ditadura civil-militar.

\section{Considerações finais}

Abordamos aqui uma das várias experiências educacionais fracassadas durante a ditadura civil-militar. As inovações propostas pelo Colégio Integrado envolveram objetivos e valores capazes de subverter o sistema educacional tradicional de maneira pouco aderente ao formalismo e à ausência de flexibilidade que marcaram as tentativas de mudanças realizadas pelos governos militares na educação. De fato, ao reunir estudos sobre as inovações educacionais no Brasil desde os anos 1930, em um momento em que o Brasil buscava uma via democrática para crises de toda a ordem, Garcia (1980, p. 11) observou que

as propostas de inovações necessitam de um clima de maior tolerância e de possibilidade de criação para que possam representar algo significativo para a educação do país (...). Parece claro que as propostas viáveis de inovação educacional exigem que os educadores e a comunidade corram o risco de ensaios e erros, avanços e retrocessos, para somente assim encontrarem formulações que atendam efetivamente às necessidades sentidas.

Talvez por isso mesmo a professora Magda Soares, em sua entrevista, tenha nos alertado para o fato de que a experiência do Colégio Integrado do Centro Pedagógico da UFMG foi "em termos históricos, uma fração de segundo na história da universidade", uma experiência que "morreu quase que antes de nascer", "uma tentativa de colocar no papel um sonho e ficou por isso mesmo... os sonhos nem sempre se realizam". ${ }^{34}$ Não havia, naquele momento, o clima de tolerância e liberdade necessário para acolher e experimentar propostas que rompessem com as orientações dominantes e que superassem o primado da disciplina em nome de uma inovação real.

No percurso desta pesquisa, nos deparamos com questões lamentavelmente atuais, não apenas pelo contexto recente de uma reforma no ensino que buscou restabelecer antigas

\footnotetext{
${ }^{34}$ Magda Soares. Belo Horizonte, 31 out. 2020 (Entrevista realizada por via remota para esta pesquisa).
} 
concepções da relação entre educação e trabalho - a Reforma do Ensino Médio empreendida no governo de Michel Temer, em 2017 - mas também pelo significado político da participação de especialistas da universidade no respaldo de políticas públicas efetivadas em contextos de enfraquecimento das instituições democráticas. Em síntese, chama a atenção como em momentos de ruptura institucional, ontem e hoje, os debates acerca do que deve ser a educação são mobilizados política e socialmente com a pretensão de inaugurar novos tempos que, na realidade, restauram velhas ordens já conhecidas.

\section{Referências}

ALVES, M. M. O beabá dos MEC-USAID. Rio de Janeiro: Gernasa, 1968.

AMADO, H.; MESQUITA, S.; DOURADO, C.; BRAZIL, C. V. Uma experiência interrompida. Rio de Janeiro: Lidador, 1972.

ARAPIRACA, J. O. A USAID e a educação brasileira: um estudo a partir de uma abordagem crítica do capital humano. Dissertação de Mestrado em Educação. Rio de Janeiro: Instituto de Estudos Avançados em Educação da Fundação Getúlio Vargas, 1979.

BELTRÃO, T. Reforma tornou ensino profissional obrigatório em 1971. Agência Senado. Brasília, 3 de março de 2017.

BRASIL. Conselho Federal de Educação. Parecer nº 853 de 12 de novembro de 1971. Núcleo-comum para os currículos de $1^{\circ}$ e $2^{\circ}$ graus. A doutrina do currículo na lei n ${ }^{\circ} 5.692$. Rio de Janeiro, 1971a.

BRASIL. Ministério da Educação e Cultura. Conselho Federal de Educação. Lei 5.692 de 11 de agosto de 1971. Reforma do ensino: $1^{\circ}$ e $2^{\circ}$ Graus. Brasília: Ministério da Educação e Cultura, 1971b.

BOSON, G. B. M. Depoimento. In: RESENDE, M. E. L.; NEVES, L. A. Universidade Federal de Minas Gerais: memória de reitores (1961-1990). Belo Horizonte: Editora UFMG, 1998.

BUFFA, E. História e filosofia das instituições escolares. In: ARAÚJO, J. C. S.; GATTI JÚNIOR, D. (org.) Novos temas em história da educação brasileira. Campinas, SP: Autores Associados; Uberlândia, MG: Edufu, 2002.

COELHO, M. V. Depoimento. In: RESENDE, M. E. L.; NEVES, L. A. Universidade Federal de Minas Gerais: memória de reitores (1961-1990). Belo Horizonte: Editora UFMG, 1998.

CORRÊA, R. L. T. Lei 5692/71: formação de professores e implicações na organização da escola. In: GONÇALVES, N. G.; RANZI, S. M. F. (orgs.). Educação na ditadura civil-militar: políticas, ideários e práticas (Paraná, 1964-1985). Curitiba: Editora UFPR, 2012.

CRUZ, T. R. Uma experiência de educação interrompida (CIEM-UnB, 1964-1971). Brasília: Plano Editora, 2001.

CUNHA, L. A. Ensino profissional: o grande fracasso da ditadura. Cadernos de Pesquisa, v. 44, n. 154, p. 912-933, out./dez. 2014. DOI: https://doi.org/10.1590/198053142913

CURY, R. J.; TAMBINI, M. I. S. B.; SALGADO, M. U. C.; AZZI, S. A profissionalização do Ensino na Lei $n^{\circ}$ 5692/71. Brasília: INEP, 1982. 
DORNELLES, L. Nova experiência pioneira: Colégio Integrado em Minas. Correio da Manhã, edição nº 23.487, Rio de Janeiro, 8 de novembro de 1969.

GARCIA, W. E. (coord.). Inovação educacional no Brasil: problemas e perspectivas. São Paulo: Cortez, 1980.

GATTI JÚNIOR, D. A história das instituições educacionais: inovações paradigmáticas e temáticas. In: ARAÚJO, J. C. S.; GATTI JÚNIOR, D. (org.) Novos temas em história da educação brasileira. Campinas, SP: Autores Associados; Uberlândia, MG: Edufu, 2002.

GERMANO, J. W. Estado militar e educação no Brasil (1964-1985). São Paulo: Cortez, 1993.

GUIA do Colégio Integrado do Centro Pedagógico, 1971.

HATOUM, M. A noite da espera (O lugar mais sombrio. Livro 1). São Paulo: Companhia das Letras, 2017.

LIRA, A. T. N. A legislação de educação no Brasil durante a Ditadura Militar (1864-1985): um espaço de disputas. Tese de Doutorado em História Social pela Universidade Federal Fluminense. Niterói, 2010.

MAGALHÃES, J. Tecendo nexos: história das instituições educativas. Bragança Paulista, SP: Edusf, 2004.

MINAS GERAIS. Parecer no 211 do Conselho Estadual de Educação de Minas Gerais. Aprovado em 20 de dezembro de 1971.

MOTTA, R. P. S. As universidades e o regime militar. Rio de Janeiro: Zahar, 2014.

OLIVEIRA, J. V. F.; FARIA FILHO, L. M. Educação e modernização: a UFMG na trajetória de um projeto modernizante (1968-1974). Revista Contemporânea de Educação, v. 14, n. 29, jan./abr. 2019. DOI: https://doi.org/10.20500/rce.v14i29.18426

PASSARINHO, J. G. Exposição de Motivos. Diário do Congresso Nacional. Brasília, 30 de junho de 1971.

PAUL, G. Inovação e esquecimento na trajetória do Colégio Universitário. Boletim da UFMG, $\mathrm{n}^{\mathrm{o}} 744$, ano 15,11 de março de 1988.

PEDROSA, J. G.; BITTENCOURT JÚNIOR, N. F. Americanismo e educação para o trabalho no Brasil: os Ginásios Polivalentes (1971-1974). Trabalho \& Educação. Belo Horizonte, v. 24, $\mathrm{n}^{\mathrm{o}} 1$, p. 11-30, jan./abr. 2015.

PEREIRA, F. C. A lei 5.692/71 doze anos depois. In: CÂMARA DOS DEPUTADOS. Educação: doze anos depois. Brasília, Câmara dos Deputados, 1985.

PIMENTA, A. Universidade: a destruição de uma experiência democrática. Petrópolis, RJ: Vozes, 1984. 
RELATÓRIO Final do Grupo de Trabalho da Reforma de Ensino de $1^{\circ}$ e $2^{\circ}$ graus, 1971. In: AGUIAR, J. M. (org.). CFE - Pareceres Básicos: Reforma - Ensino de $1^{\circ}$ e $2^{\circ}$ graus. Brasília: MAI Editora, 1975.

RELATÓRIO da Comissão Anísio Teixeira de Memória e Verdade da Universidade de Brasília. Brasília: FAC-UnB, 2016.

ROMANELLI, O. História da Educação no Brasil (1930-1973). Petrópolis, RJ: Vozes, 1986.

SAVIANI, D. O Congresso Nacional e a educação brasileira: significado político da ação do Congresso Nacional no processo de elaboração das leis $n^{\circ}$ 4024/61, 5540/68 e 5672/71. Tese de livre-docente de História da Educação apresentada na Universidade Estadual de Campinas. Campinas: UNICAMP, 1986.

SAVIANI, D. História das ideias pedagógicas no Brasil. Campinas, SP: Autores Associados, 1999. SOARES, Magda. Metamemória-memórias: travessia de uma educadora. São Paulo: Cortez, 1991. 